\title{
A content analysis study of scientific approach and authentic assessment in the textbook of Curriculum 2013
}

\author{
Maryati Maryati *, Enny Zubaidah, Ali Mustadi \\ Department of Primary Education, Graduate School of Universitas Negeri Yogyakarta. \\ Jalan Colombo No. 1, Karangmalang, Yogyakarta 55281, Indonesia \\ * Corresponding Author. E-mail: maryatimars@yahoo.com \\ Received: 22 August 2019; Revised: 3 October 2019; Accepted: 10 October 2019
}

\begin{abstract}
This research aimed to describe the scientific approach and authentic assessment of the textbook based Curriculum 2013, on the theme "save living beings" for grade 6 students of elementary school such as textbooks published by Puskurbuk, Yudhistira, and Erlangga. The design of this study was content analysis. The instrument of the research was the analysis sheet based on theories. The validity of the instrument and the data was semantic validity and expert judgment. The reliability of the data was stability and reproducibility. The techniques of data analyzing consisted of unitizing, sampling, recording, reducing, inferring and narrating. The results of this study were; (1) The scientific approach contents consist of five aspects: observation, questions, trying, reasoning, and communicating, which are not in order. So not all indicators in every aspect of the scientific approach are found in each subtheme. (2) Authentic assessment contents consist of three aspects: attitude assessment about social attitude and spiritual attitude; the psychomotor assessment contains only practice, product, and project assessment, and knowledge assessment without oral and assignment assessment.

Keywords: content analysis, authentic assessment, scientific approach.

How to Cite: Maryati, M., Zubaidah, E., \& Mustadi, A. (2019). A content analysis study of scientific approach and authentic assessment in the textbook of Curriculum 2013. Jurnal Prima Edukasia, 7(2), 128-138. doi:https://doi.org/10.21831/jpe.v7i2.26792
\end{abstract}

do https://doi.org/10.21831/jpe.v7i2.26792

\section{Introduction}

The learning process is not only about teachers and students, but also learning tools. The textbook is an example of learning tools. Today, the textbook of curriculum 2013 is used for the current Curriculum 2013. The textbook of Curriculum 2013 is a learning tool used by the schools which aim to support the learning process. This book becomes a source of information that, hopefully, could help students in learning and achieve the goals of learning. Also, the textbook is used as a reference for teachers and students in the learning process. Therefore, the textbooks must refer to the process and assessment in Curriculum 2013.

The process and assessment of learning in the Curriculum 2013 use a scientific approach and authentic assessment. Scientific might define as an approach that uses to develop the activeness and creativity of students. Because, the approach contains important components such as observing, questioning, reasoning, experimenting and communicating, which have a function to support the learning process. While the authentic assessment is an assessment that directly measures the real performance of students in certain matters.

The scientific approach must touch on three domains, namely attitudes, knowledge, and skills. The attitude aspect contains teaching material which aims the students know "why." The knowledge aspect contains teaching material which aims the students know "what." While the skills aspect contains teaching material which aims the students know "how." In the end, hope, there are an increase and balance between soft and hard skill among students, including the aspects of competence in attitude, knowledge, and skills.

The assessment standard in the curriculum 2013 is authentic assessment. An authentic assessment is an activity of evaluating the students that emphasize the things should be assessed both the process and the results of various assessment instruments, that are adjusted to the competency demands in the core competencies (CC) and basic competencies (BC). 
Authentic assessment measures competencies of attitude, skills, and knowledge, based on process and results. The results of authentic assessment are used by teachers to plan programs.

Referring to the Curriculum 2013, which uses a scientific approach and authentic assessment, then, the textbooks must also be prepared using a scientific approach and containing an authentic assessment. Therefore, the textbook needs a review in terms of the application of scientific approaches and authentic assessments, whether it has facilitated students in activities or not (Cumming \& Maxwell, 1999; Dewanti et al., 2018; Wijaya, 2013, p. 57).

Many publishers of the textbook of Curriculum 2013 are found on the market. Observation on July 5 and July 9, 2018, textbooks of Curriculum 2013 that found in stores in Yogyakarta Special Region are Platinum, Triad, Yudhistira, Erlangga, Grasindo, Esis, and Masmedia. Besides, observations made at 15 elementary schools for piloting projects of curriculum 2013 in Bantul Regency. The result shows that teachers are still using learning and assessment processes according to textbooks of Curriculum 2013 that have not been analyzed in terms of scientific approaches and authentic assessments even though these two aspects are an inseparable part of the curriculum 2013.

The analyzed textbook of Curriculum 2013 was the textbook used by 15 elementary schools for piloting projects of curriculum 2013 in Bantul Regency. Based on the survey, the textbook mostly used and published by the private sector was Yudhistira and Erlangga in 2018.

Textbook on theme 1 "Save living Beings" for grade 6, published by several publishers, becomes the textbooks in teaching and learning activities. These books become complementary books in the implementation of the Curriculum 2013. Therefore, as the initial book for the learning process, the books should contain essential aspects of the Curriculum 2013, especially aspects of the scientific approach and authentic assessment to reach better learning.

The research aimed to; (1) describe the scientific content in the textbooks of curriculum 2013 , (2) describe the authentic assessment content in the textbooks of Curriculum 2013, and (3) compare the scientific content and authentic assessments content in the textbooks of Curriculum 2013.

Shamsudin, Abdullah, and Yaamat (2013) states that "Teaching science is not about preparing students for a world that is static and fixed, but it concerns getting students ready to cope with changes and challenges in their life." Therefore, learning is not only to develop the student competencies, but it also develops the knowledge and thinking skills of the students to create creative and innovative people. The scientific approach, as one of the approaches, might use a tool to reach the goal of the learning in the Curriculum 2013.

Fadlillah (2014, p. 176) explains a scientific approach is an approach of learning through the process of observing, asking, trying, reasoning, and communicating. The activity can maximize in building the students' attitudes, skills, and knowledge. The five scientific learning processes are implemented on the core learning activities.

According to (Mak et al., 2009, p. 18), "observation does not necessarily mean that we have to see it with our own eyes. We have five senses. Sight is only one of them. The others are hearing, taste, touch, and smell." (Goldston \& Downey, 2013, p. 132) add that "it is important to encourage students to use all their senses (visual, auditory, tactile, olfactory, and taste when appropriate) to provide maximum information when observing science events or phenomena."

The activity of questioning is arranged by making and asking questions, asking about information, question and answer, and clarification. As stated by (Chiappetta \& Koballa, 2010, p. 130), "questions can engage thinking and orient mental activity toward meaningful ends." Questions can stimulate students' thinking skills that are useful in learning activities, which have an impact on students' understanding.

Learning activities at the stage of trying are exploring, trying, discussing, demonstrating, imitating forms/movements, experimenting, reading sources other than textbooks, collecting data from sources through questionnaires, interviews, and modifying/adding/developing.

Zaim (2017, p. 34) states "associating is the process of analyzing the information to find the relationship between one information to other information and to find the patterns of the interrelationship of the information so that one can make conclusions from the patterns found." (Gerde et al., 2013, p. 318) suggest that reasoning activities are summarizing and analyzing results to conclude. Collecting different findings from the experimental stage aims to answer the questions raised.

Settlage \& Southerland (2012, p. 92) suggest that communicating activities are very 
important. Communicating is an important tool in learning activities, but teachers need to aim at writing activities as the main tool of communication. Communicating sometimes defines as a means of sharing information, such as writing, speaking, or using other forms. Communicating is also able to help one to learn through the process of exchanging information.

An authentic assessment deals with authentic learning. The focus of authentic assessment is to measure student competency in learning activities, while the focus of authentic learning involves student activity in the learning process. As stated by (Eddy \& Lawrence, 2013, p. 6), "authentic learning involves active engagement in the learning process, whereas authentic assessment focuses on evaluating student work that puts knowledge to practice."

Authentic assessment in the implementation of the Curriculum 2013 refers to the assessment standards, consisting of (1) assessment of attitude competency through observation, selfassessment, peer assessment by students and journals, (2) knowledge through written tests, oral tests, and assignments, and (3) skills through performance appraisal, namely assessments that require students to demonstrate a certain competency using practice tests, products, projects, and portfolios.

Attitude assessment is an activity carried out by educators to obtain descriptive information about student behaviour. Attitude assessment includes spiritual and social attitudes. Educators conduct attitude assessments through self-assessment, peer assessment, observation assessment, and journals. The instruments of self-assessment, peer assessment, observation assessment are rating scales or checklists completed by rubrics, while journals are teacher's notes.

Skills assessment is an assessment to measure students' ability in applying knowledge

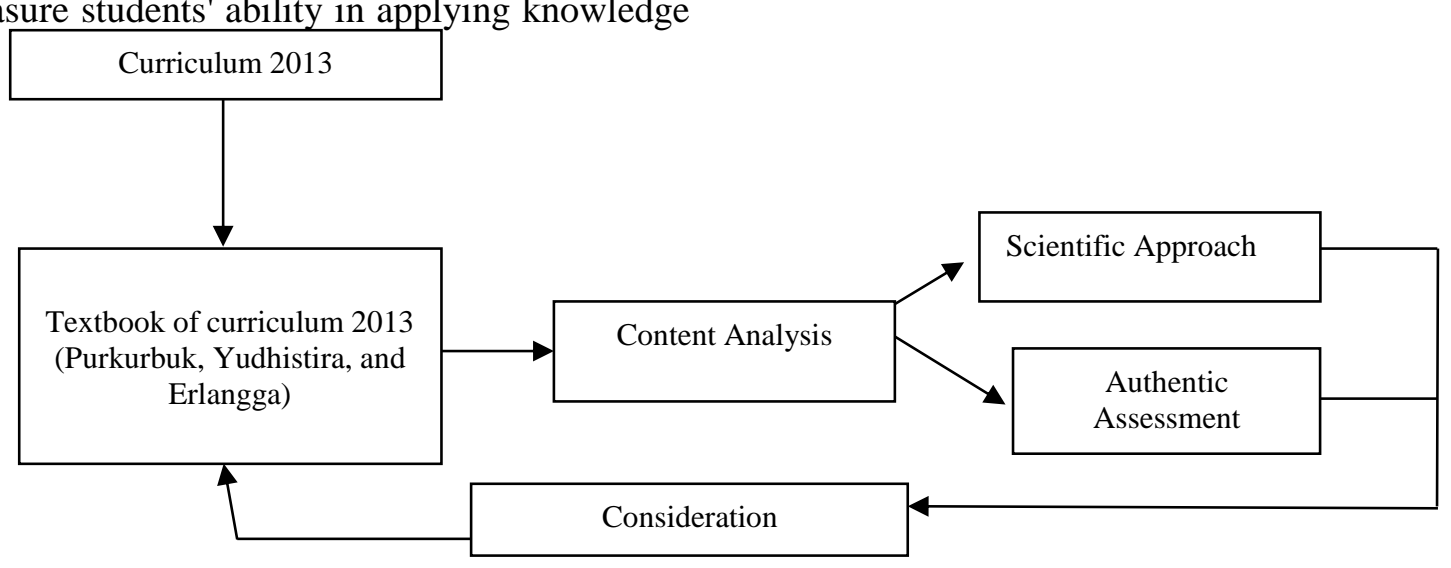

Figure 1. Framework and do specific tasks. Types of skills assessment consist of assessing practices, products, projects, and portfolios. The instruments in the assessment are rating scale or checklist completed by a rubric.

Knowledge assessment consists of written tests, oral tests, and assignments. The curriculum 2013 requires students to formulate their answers, such as an essay. In line with (Nitko \& Brookhart, 2011, p. 248), those written tests require students not only to record their answers, but also provide explanations, articulate their reasons, and express their approaches toward problem-solving. The activity is an essay. (Joughin, 2010, p. 3) explains, Oral assessment refers to any assessment of student learning that is conducted by the spoken word. The framework of this study illustrated in the chart in Figure 1.

In curriculum 2013, it explains that thematic teaching materials were in the form of textbooks based on the curriculum 2013. The textbooks were used by schools in learning activities that published by Puskurbuk, Yudhistira, and Erlangga. The textbooks use to reach maximum teaching and learning activities.

Textbooks published by Purkurbuk, Yudhistira, and Erlangga that are used in Curriculum 2013, must have learning characteristics of the Curriculum 2013. The particular study analyzed textbooks of the Curriculum 2013 published by Purkurbuk, Yudhistira, and Erlangga, seen from the contents of the scientific approach and authentic assessment due to they are the main components in the implementation of the curriculum 2013. Then, analysis results, hopefully, provide an overview of the contents of the textbook which becomes the inputs and suggestions on the learning activities, as well as for the publisher, author, and BSNP for improvement. 


\section{Method}

The research type was content analysis. The particular research was content analysis research in which the research data sources were textbooks of the curriculum 2013, published from three publishers (Puskurbuk, Yudhistira, and Erlangga). So, the analysis was not limited by location/place. The survey of textbook Curriculum 2013-based conducted to elementary schools for piloting projects of Curriculum 2013 in Bantul Regency. The particular research conducted on October 2018 - March 2019.

Data sources consisted of subjects and objects of the research. The subject was textbooks of the curriculum 2013 of grade VI, on themes of "Save the Living Being" published by Puskurbuk, Yudhistira, and Erlangga. The selection of textbooks was by the number of textbooks mostly used by 15 elementary schools for piloting projects of Curriculum 2013 in Bantul Regency.

The objects were a scientific approach and an authentic assessment. The scientific approach is examined from the content of the five activities namely observing, asking, trying, reasoning, and communicating. Meanwhile, authentic assessment is examined from the assessments contained in the textbook of Curriculum 2013-based associated with learning and learning outcomes.

The analysis unit was three textbooks of Curriculum 2013 published by Puskurbuk, Yudhistira, and Erlangga. The analyzed components were the content of scientific and authentic assessments in the textbook. Data collection techniques were careful reading and note-taking, proposed by Krippendorf (2013: 85), toward the textbook of the curriculum 2013, grade VI on the theme, "Save Living Beings." A careful reading and note-taking is an analysis of the contents of a scientific approach and authentic assessment. The objective analysis was reading the textbook repeatedly and note taking the findings carefully during the reading. Data collection conducted to obtain an idea of how the contents of the scientific approach and authentic assessment in textbooks. After the data properly collected, it continued to data analysis to obtain the findings and draw a conclusion.

The data analysis was words or sentences, by consideration: (1) adjusting the instrument with data collection techniques; (2) analyzing the scientific approach and authentic assessment in textbooks of Curriculum 2013. The analysis was compiled based on the study of scientific approach theory and authentic assessment using the instrument grid. After that, it developed into instruments, such as in Table 2 and Table 3 . From Table 2 and Table 3, St is Subtheme (subtema), $\mathrm{Pb}$ is Learning (Pembelajaran), No is Number, and Hal is Page (Halaman). Data analysis technique, proposed by (Krippendorff, 2018, pp. 8486), consisted of unit selection, theme determination, data collection, data reduction, drawing conclusions, and narrating. Semantic validity and inspection by experts used for the validity of the instruments and data. Reliability was stability and reproducibility.

Table 1. List of Textbook of Curriculum 2013 used by elementary schools for piloting projects of curriculum 2013 in Bantul Regency

\begin{tabular}{|c|c|c|}
\hline No. & Publisher & Number of Schools \\
\hline 1. & Puskurbuk & 15 \\
\hline 2. & Yudhistira & 3 \\
\hline 3. & Erlangga & 5 \\
\hline 4. & Tiga Serangkai & - \\
\hline 5. & Grasindo & - \\
\hline 6. & Esis & - \\
\hline 7. & Masmedia & - \\
\hline
\end{tabular}

Table 2. Scientific Instrument Sheet

\begin{tabular}{lllllll}
\hline \multirow{2}{*}{$\mathrm{St}$} & $\mathrm{Pb}$ & \multirow{2}{*}{$\mathrm{No}$} & \multirow{2}{*}{ Text } & \multirow{2}{*}{ Page } & \multicolumn{3}{c}{ The Content of The Scientific Approach } \\
\cline { 5 - 6 } & & Observing & Asking & Trying & Reasoning \\
\hline
\end{tabular}

Table 3. Authentic Assessment Instrument Sheets

The Contents of the Authentic Assessment

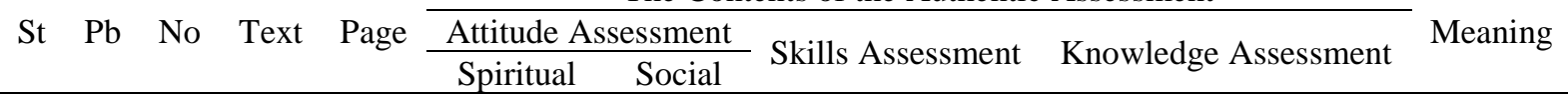




\section{Result and Discussion}

Result

This section presents the finding and discussion. Findings and discussion refer to the problem of the study. The problem relates to the scientific approach and authentic assessment of the textbook of the Curriculum 2013, grade VI on the theme, "Save Living Beings."

\section{Scientific Content}

The following description is the finding on the content analysis of scientific approach variables of the textbook of the Curriculum 2013 that presented based on numbers.

Based on the Table 4, the highest number the aspects of observing, asking and reasoning are textbook published by Puskurbuk. The highest number the aspects of trying and communicating are textbook published by Yudhistira.

\section{Authentic Assessment Content}

The following description is the finding on the content analysis of authentic assessment vari- ables of the textbook of the Curriculum 2013 that presented based on numbers. Based on Table 5 , the highest number of aspects of attitude assessment are textbook published by Puskurbuk. The highest number of aspects of skill and knowledge assessment is a textbook published by Yudhistira.

Comparison the Contents of Scientific Approaches and Authentic Assessments in Textbooks of Curriculum 2013

Table 6 is a comparison of the results of the content analysis of the textbook based on its completeness. The description of the table is $\mathrm{P}$ "Puskurbuk", Y "Yudhistira", and E "Erlangga". The textbook of Curriculum 2013 published by Puskurbuk and Erlangga is a comprehensive book in term of observing aspects because provides 4 indicators. The textbook published by Puskurbuk meets the indicators of reading, listening, hearing and seeing. The textbook published by Erlangga meets the indicators of reading, listening, touching, and seeing. While the textbook published by Yudhistira only meets 2 indicators, namely reading and seeing

Table 4. Result of Content Analysis of Scientific Approach Variables of the Textbook of the Curriculum 2013 that Presented based on Numbers

\begin{tabular}{|c|c|c|c|c|c|c|c|c|c|c|c|c|c|c|}
\hline \multirow{2}{*}{ Variable } & \multirow{2}{*}{ Aspect } & \multirow{2}{*}{ Indicators of Aspects } & \multicolumn{4}{|c|}{ Puskurbuk } & \multicolumn{4}{|c|}{ Yudhsitira } & \multicolumn{4}{|c|}{ Erlangga } \\
\hline & & & 1 & 2 & 3 & $\sum$ & 1 & 2 & 3 & $\sum$ & 1 & 2 & 3 & $\sum$ \\
\hline Scientific & Observing & Reading & 28 & 33 & 19 & 80 & 17 & 12 & 10 & 39 & 18 & 17 & 18 & 53 \\
\hline \multirow[t]{23}{*}{ Approach } & & Listening/hearing & - & 2 & - & 2 & - & - & - & - & - & - & - & - \\
\hline & & Listening & - & 2 & 1 & 3 & - & - & - & - & - & 2 & - & 2 \\
\hline & & Smelling & - & - & - & - & - & - & - & - & - & - & - & - \\
\hline & & Feeling & - & - & - & - & - & - & - & - & - & - & - & - \\
\hline & & Touching & - & - & - & - & - & - & - & - & - & - & - & - \\
\hline & & Seeing/looking & 18 & 20 & 13 & 51 & 22 & 17 & 14 & 53 & 22 & 13 & 18 & 53 \\
\hline & Asking & $\begin{array}{l}\text { Making and Asking the } \\
\text { Question }\end{array}$ & 1 & - & - & 1 & 1 & 2 & 1 & 4 & - & - & - & - \\
\hline & & Question and Answer Activity & 1 & 1 & 1 & 3 & 0 & 1 & - & 1 & 3 & - & 1 & 4 \\
\hline & & Asking an information & 10 & 11 & 6 & 27 & 5 & 6 & 4 & 15 & 7 & 10 & 6 & 23 \\
\hline & Trying & Exploring & 10 & 1 & 8 & 19 & 20 & 13 & 13 & 46 & 6 & 12 & 6 & 24 \\
\hline & & Trying & 8 & 16 & 13 & 37 & 2 & 2 & 2 & 6 & 2 & 2 & 7 & 11 \\
\hline & & Demonstrating & - & - & - & - & - & - & - & - & - & - & - & - \\
\hline & & Imitating the form/motion & - & - & - & - & - & - & - & - & - & - & - & - \\
\hline & & Experimenting & - & - & - & - & 1 & - & - & 1 & - & - & - & - \\
\hline & & $\begin{array}{l}\text { Reading sources othen than } \\
\text { textbooks }\end{array}$ & - & - & - & - & 2 & - & 1 & 3 & - & - & 1 & 1 \\
\hline & & Data collection & 2 & 1 & - & 3 & 4 & 9 & 5 & 18 & 1 & 1 & 3 & 5 \\
\hline & Reasoning & $\begin{array}{l}\text { Processing the collected } \\
\text { information }\end{array}$ & 10 & 9 & 4 & 23 & - & 5 & 3 & 9 & 7 & 6 & 4 & 17 \\
\hline & & Analyzing data into category & 1 & 1 & - & 2 & - & 1 & - & 1 & - & - & - & - \\
\hline & & $\begin{array}{l}\text { Associating the } \\
\text { phenomena/information }\end{array}$ & 4 & 2 & 7 & 13 & 2 & - & - & 2 & 1 & 7 & 11 & 20 \\
\hline & & Concluding & 2 & 2 & 4 & 8 & 4 & 8 & 5 & 17 & 8 & 14 & 11 & 33 \\
\hline & Communicating & Presenting a written report & 8 & 3 & 5 & 16 & 8 & 4 & 4 & 16 & 5 & 6 & 1 & 12 \\
\hline & & $\begin{array}{l}\text { Presenting reports in the form } \\
\text { of concept maps/figures/ tables }\end{array}$ & 7 & 6 & - & 13 & 9 & 7 & 4 & 20 & 9 & 6 & 3 & 18 \\
\hline & & Present reports verbally & 8 & 3 & - & 11 & 2 & 6 & 3 & 11 & 3 & 4 & 6 & 13 \\
\hline
\end{tabular}


Jurnal Prima Edukasia, 7 (2), 2019 - 133

Maryati Maryati, Enny Zubaidah, Ali Mustadi

Table 5. Result of Content Analysis of Authentic Assessment Variables of the Textbook of the Curriculum 2013 that Presented based on Numbers

\begin{tabular}{|c|c|c|c|c|c|c|c|c|c|c|c|c|c|c|}
\hline \multirow{2}{*}{ Variables } & \multirow{2}{*}{ Aspect } & \multirow{2}{*}{$\begin{array}{c}\text { Indicators of } \\
\text { Aspect }\end{array}$} & \multicolumn{4}{|c|}{ Puskurbuk } & \multicolumn{4}{|c|}{ Yudhsitira } & \multicolumn{4}{|c|}{ Erlangga } \\
\hline & & & 1 & 2 & 3 & $\sum$ & 1 & 2 & 3 & $\sum$ & 1 & 2 & 3 & $\sum$ \\
\hline Authentic & Attitude & Self-evaluation & 6 & 6 & 6 & 18 & 2 & 2 & 2 & 6 & - & - & - & - \\
\hline \multirow[t]{10}{*}{ Assessment } & Assessment & Peer & - & - & - & - & - & - & - & - & - & - & - & - \\
\hline & (spiritual \& social) & Observation & - & - & - & - & - & - & - & - & - & - & - & - \\
\hline & & Journal & 2 & 4 & 3 & 9 & - & - & - & - & - & - & - & - \\
\hline & Skills assessment & Practice & 40 & 29 & 27 & 96 & 33 & 29 & 26 & 88 & 26 & 26 & 26 & 78 \\
\hline & & Product & - & - & - & - & 3 & 4 & 2 & 9 & 2 & 2 & 2 & 6 \\
\hline & & Projeck & - & - & - & - & - & - & 5 & 5 & - & - & - & - \\
\hline & & Portfolio & - & - & - & - & - & - & - & - & - & - & - & - \\
\hline & Knowledge & Written Test & 13 & 5 & 7 & 25 & 12 & 12 & 12 & 36 & 25 & 5 & 7 & 25 \\
\hline & Assessment & Oral Test & - & - & - & - & - & - & - & - & - & - & - & - \\
\hline & & Assignment & - & - & - & - & - & - & - & - & - & - & - & - \\
\hline
\end{tabular}

Table 6. Comparison the Results of Content Analysis of the Textbook of Curriculum 2013 based on its Completeness

\begin{tabular}{|c|c|c|c|c|c|}
\hline Variable & Aspect & Indicators of Aspect & $\mathrm{P}$ & Y & $\mathrm{E}$ \\
\hline Scientific & Observing & Reading & $\sqrt{ }$ & $\sqrt{1}$ & $\sqrt{ }$ \\
\hline \multirow[t]{23}{*}{ approaches } & & Listening/Hearing & $\sqrt{ }$ & - & - \\
\hline & & Listening & $\sqrt{ }$ & - & $\sqrt{ }$ \\
\hline & & Smelling & - & - & - \\
\hline & & Feeling & - & - & - \\
\hline & & Touching & - & - & $\sqrt{ }$ \\
\hline & & Seeing/looking & $\sqrt{ }$ & $\sqrt{ }$ & $\sqrt{ }$ \\
\hline & Asking & Making and Asking Question & $\sqrt{ }$ & $\sqrt{ }$ & $\sqrt{ }$ \\
\hline & & Question and Answer & $\sqrt{ }$ & $\sqrt{ }$ & $\sqrt{ }$ \\
\hline & & Asking an information & $\sqrt{ }$ & $\sqrt{ }$ & $\sqrt{ }$ \\
\hline & Trying & Exploring & $\sqrt{ }$ & $\sqrt{ }$ & $\sqrt{ }$ \\
\hline & & Trying & $\sqrt{ }$ & $\sqrt{ }$ & $\sqrt{ }$ \\
\hline & & Demonstrating & - & - & - \\
\hline & & Imitating the form/ motion & - & - & - \\
\hline & & Experimenting & - & $\sqrt{ }$ & - \\
\hline & & Reading other sources & - & $\sqrt{ }$ & $\sqrt{ }$ \\
\hline & & Data Collection & $\sqrt{ }$ & $\sqrt{ }$ & $\sqrt{ }$ \\
\hline & Reasoning & Processing the collected information & $\sqrt{ }$ & $\sqrt{ }$ & $\sqrt{ }$ \\
\hline & & Analyzing data into category & $\sqrt{ }$ & $\sqrt{ }$ & $\sqrt{ }$ \\
\hline & & Associating the phenomena/information & $\sqrt{ }$ & $\sqrt{ }$ & $\sqrt{ }$ \\
\hline & & Concluding & $\sqrt{ }$ & $\sqrt{ }$ & $\sqrt{ }$ \\
\hline & Communicating & Presenting written report & $\sqrt{ }$ & $\sqrt{ }$ & $\sqrt{ }$ \\
\hline & & $\begin{array}{l}\text { Presenting reports in the form of concept } \\
\text { maps/figures/tables }\end{array}$ & $\sqrt{ }$ & $\sqrt{ }$ & $\sqrt{ }$ \\
\hline & & Presenting the report verbally & $\sqrt{ }$ & $\sqrt{ }$ & $\sqrt{ }$ \\
\hline Authentic & Attitude Assessment & Self-evaluation & $\sqrt{ }$ & $\sqrt{ }$ & - \\
\hline \multirow[t]{10}{*}{ Assessment } & (Spiritual and Social) & Peer & - & - & - \\
\hline & & Observation & - & - & - \\
\hline & & Journal & $\sqrt{ }$ & - & - \\
\hline & Skill Assessment & Practice & $\sqrt{ }$ & $\sqrt{ }$ & $\sqrt{ }$ \\
\hline & & Product & - & $\sqrt{ }$ & $\sqrt{ }$ \\
\hline & & Projeck & - & $\sqrt{ }$ & - \\
\hline & & Portfolio & - & - & - \\
\hline & Knowledge & Written Test & $\sqrt{ }$ & $\sqrt{ }$ & $\sqrt{ }$ \\
\hline & Assessment & Oral Test & - & - & - \\
\hline & & Assignment & - & - & - \\
\hline
\end{tabular}

In the asking aspect, the three textbooks published by Puskurbuk, Yudhistira, and Erlangga are both comprehensive because they meet 3 indicators, namely; making and asking questions, question and answer activities, and asking information. In the aspect of trying, the 
textbooks published by Yudhistira become the most comprehensive textbooks because contain 5 indicators, namely; exploring, trying, experimenting, reading other sources and data collection, while the textbooks published by Erlangga contain 4 indicators and Puskurbuk contain 3 indicators.

In the reasoning aspect, the three textbooks published by Puskurbuk, Yudhistira, and Erlangga are comprehensive because of meet 4 indicators, namely; processing the collected information, analyzing data into categories, associating phenomena/information, and concluding. Also, in the aspect of communicating, they are comprehensive because they contain 3 indicators, namely; presenting written reports, presenting reports in the form of concept maps/figures/ tables, and presenting reports verbally.

In the aspect of attitude assessment, the textbook published by Puskurbuk is the most comprehensive because it meets 2 indicators, namely self-assessment, and journals. While, the textbook published by Yudhistira meets 1 indicator, namely self-assessment. And, a textbook published by Erlangga does not contain a single indicator.

In the aspect of skills assessment, the textbooks published by Yudhistira and Erlangga are comprehensive because of meet 2 indicators, namely; the assessment of practices and products. While, the textbook published by Puskurbuk only contains 1 indicator, namely the assessment of practice. And, in the aspect of knowledge assessment, all three textbooks are comprehensive because contain written test indicators.

Based on the explanation, in the aspect of the scientific approach, the most comprehensive textbook is the textbook published by Erlangga because has the highest number of indicators for the indicators of scientific approach. While in the authentic assessment aspect, textbooks published by Puskurbuk and Yudhistira are comprehensive because have the same number of indicators fulfilled.

\section{Discussion}

\section{The content of Scientific Approach}

The textbook of Curriculum 2013 published by Puskurbuk, Yudhistira, and Erlangga have aspects of observing with different indicators. The indicators of reading and seeing found in every learning of the textbook of curriculum 2013. The listening/hearing indicator only found in textbooks published by Puskurbuk. The listen- ing indicators found in textbooks published by Puskurbuk and Erlangga. The touching indicator only found in a textbook published by Erlangga. The indicators of feeling and smelling were not found in all the analyzed textbooks.

Observing activities are useful for students' curiosity in finding facts related to the object being analyzed according to the content of the learning need. This activity is used to collect data directly and carefully to the field with the aim the students obtain a picture of the state of the field. Through students' observation, students gain accurate data about the object being observed. According to (Mak et al., 2009, p. 18) states that "observation does not necessarily mean that we have to see it with our own eyes. We have five senses. Sight is only one of them. The others are hearing, taste, touch, and smell."

Using the senses is the characteristic of observing activities. The textbook found observing indicators, such as reading, seeing, listening, hearing and feeling. Reading and seeing use the sense of sight, hear and listen using the sense of hearing, and touch using the sense of touch. The results of this analysis contrast with (Goldston \& Downey, 2013, p. 132) which states that "it is important to encourage students to use all their senses (visual, auditory, tactile, olfactory, and taste when appropriate) to provide maximum information when observing science event or phenomenon." The analysis results of the textbook found no indicators of smelling and feeling.

The questioning aspect found in all three textbooks. This aspect consists of indicators of making and asking questions, question and answer activities, and asking questions of information. (Dyer et al., 2011, p. 68) states that "questions hold the poten-tial to cultivate creative insights." Therefore, in the questioning activity, the teacher provides opportunities for students to ask questions about what they have listened to, read, or seen. The teacher needs to direct students to ask questions about the results of observations that are concrete to the abstract. This appropriate with the cha-racteristics of grade VI students who understand concrete objects to begin to understand abstract objects.

When students have difficulty in asking questions, teachers need to assist them to able to ask questions until they can ask questions independently. The ability through questioning aspects is curiosity, creativity, and the skill to make questions to increase the critical thinking skills. (Chiappetta \& Koballa, 2010, p. 130) 
states that "questions can engage thinking and orient mental activity toward meaningful ends."

The trying aspects of the textbooks consisted of indicators of exploring, trying, experimenting, reading other sources, and collecting data. These indicators appear varied. Aspects of trying conducted by students aim to construct knowledge.

The exploring indicators in the textbooks consisted of exploring images, reading texts, and the environment. This activity is carried out after the activity of seeing and reading on observing aspects. Students interact with the physical and natural environment. (Schunk, 2012, p. 334) states that learning occurs when students experience cognitive conflict and involve in the process of assimilation and accommodation which aim to build internal structures for understanding information. Learning with interaction activities toward the physical and natural environment helps students to build internal structures.

Indicators of trying are the application of knowledge and understanding the information of the textbooks. Indicators of trying have the purpose to apply the knowledge and understanding which obtained from the information or follow instructions in the textbook. Furthermore, the indicator of experimenting is a series of structured activities to gain knowledge. (Ongowo \& Indoshi, 2013, p. 715) states that "testing by following procedures to produce verifiable results." These results related to the initial knowledge possessed by students. Experiments have the purpose to facilitate the strengthening of understanding because students are directly engaged in the activities of gaining knowledge.

Indicators of reading other sources are activities to inspire further activities. Reading activities other than textbooks inspire them in making work, summaries, and reports. While indicators of collecting data have the purpose to obtain information from various sources. The analysis results of the textbook found that the indicators of collecting information were carried out through direct observation, interviews, and literature study. According to Schunk (2012), the social environment influences cognition through its "tools," which called the cultural objects, as well as language and intuitions (Schunk, 2012). Therefore, social interaction is needed in learning activities.

Reasoning aspects of the textbook are processing the collected information, analyzing the data into categories, connecting phenomena/ information and concluding. Also, Piaget in
(Boyd et al., 2012, pp. 50-51), states elementary students have classification abilities. The ability is the ability to categorize and focus on relationships between categories. The process of reasoning might develop by the teacher by encouraging students to engage in question and answer activities by pushing them to think critically and complexly. The thinking process in a scientific approach is inductive because they try to gain knowledge.

A scientific approach to the communicating aspect is found in all textbooks. The indicator consists of presenting written reports, presenting reports in concept maps/figures/tables, and presenting verbal reports. Supported by (Settlage $\&$ Southerland, 2012, p. 92), "communicating activities are very important." Communicating is an important tool in learning activities. But, teachers need to bring the students to writing activities as the main means of communication. Communicating sometimes consider as a means of sharing the information, whether in writing, speaking, or using another form. Communicating is also able to help someone to learn through the process of sharing information.

In communicating activities, students could able to communicate the results of the arranged work either in groups or individually from the conclusions. (Kovalik \& Olsen, 2010, p. 57) supports that "communicating is the scientific process that allows one to share interpretation, to clarity, correct and expand one's understanding, to explore applications to the real world and to determine relevance to one's own life."

Communicating activities conducted to increase student's confidence and courage in front of the public. Other students can provide constructive comments, suggestions, and opinions when their fellow friends make a presentation. The expected skills that develop through the activities are tolerance, conscientious, honest, expressing opinions, and improving language skills.

\section{Content of Authentic Assessment}

The textbooks that have self-assessment are textbooks published by Puskurbuk and Yudhistira. Self-assessment is a self-evaluation conducted by students. This self-assessment is used to reflect on and evaluate the results of their work. In line with (Spiller, 2012, p. 4) states, "why self-assessment ... self-evaluation encourages reflection on one's own learning."

Self-assessment could use to measure attitudes, knowledge, and skills. Self-assessment, 
as stated by (Asep \& Abdul, 2008, p. 116), asks students to assess themselves associated with the status, process, and level of achievement of the competencies they learn. Self-assessment allows students to take responsibility. They can write what they feel. Also, the Ministry of Education and Culture (2016) states, that self-assessment asks students to assess themselves in terms of strengths and weaknesses in achieving competence (Direktorat Pembinaan Sekolah Dasar, 2016).

In addition to self-assessment, observing assessments are also found in the textbooks. Observing assessments are carried out by the teacher during the learning. Indicators of attitude observing assessment are found in the textbooks, such as caring, responsible, discipline, and cooperation. These attitudes are observed by the teacher during the learning process. (Asep \& Abdul, 2008, p. 69) states that the assessment of observing is an assessment made by teachers based on the observations toward the student's behavior, that might be individuals or groups, inside or outside the classroom.

The attitude assessment of the textbook also shows the journal assessment. The journal assessment is used to observe student attitudes and performance during the learning process. The attitude that was observed based on the evaluation of journals in the textbooks published by Puskurbuk and Erlangga was caring, responsibility, discipline, and cooperation. The Puskurbuk book adds a journal assessment to record sports skills (PJOK) and sculpture performance (SBdP). Journal assessments are presented descriptively by the teacher. Journal evaluation is a reflection of developing documents over the learning activities.

Attitude assessment used to assess attitudes as the impact of the purpose of learning aspects of knowledge and skills. Attitude assessment covers spiritual and social attitudes. Attitude assessment can show the attitude under the indicators. These attitudes become learning objectives, but to achieve the goal is carried out indirectly.

The attitude assessment of the textbook is in line with (Boyd et al., 2012, p. 120) that schools provide a source of ideas for selfbuilding. Therefore, students can find themselves through teacher and student interactions. Textbooks are teaching materials containing learning activities that could have an impact to build student attitudes that are expected to develop.
Skills have a close relationship with students' physical development. Physical development includes fine and rough motor activities. According to (Berk, 2013, p. 377), "activities which include fine motoric skills for students are writing, drawing and playing music. While rough motor skills are associated with agility, balance, flexibility, and strength."

The analysis results of the textbook showed the assessment of practices, products, and projects as a realm of skills assessment. This skills assessment consists of assignments and scoring rubrics to assess students when carrying out activities. The scoring rubric must refer to the task as a form of implementing the learning indicators according to basic competencies. However, not all skills assessments in the textbooks describe the scoring rubric. The absence of the scoring rubric makes the teacher creative in assessing the skills of the student.

According to Saefuddin \& Berdiati (2014, p. 81), assessment of practice is an assessment that requires responses of skills to do activities or behaviours following the demands of competency. Assessment of practice is done by observing the student activities in doing something. (Van Blerkom, 2009, p. 147) suggests that in the assessment of practice, students should do several activities, while the teacher observed them. The teacher evaluates them on the activity of task completion. Also, the teacher must focus on the results or products produced by students.

The analysis also found another assessment of skills, which are project assessment. Project assessment is the activity of evaluating a task that must complete during a certain period. The task is a set of activities that start from planning, data collection, organizing, processing and data display.

Skills assessment invites teachers to facilitate their students in performing detail activities. On the other hand, the teacher must also focus on student performance and products. The teacher needs to train the students to think step by step until they complete the performance.

The aspect of knowledge assessment found in the textbooks is the written test. The questions of multiple-choice, matchmaking and short essay, is contrasted with the principle of authentic assessment. This assessment is a traditional type of assessment. In line with (Nitko \& Brookhart, 2011, p. 248), written tests require students, not only to record their answers, but also provide explanations, explain their reasons, and express their approaches to problem-solving. The activity 
in question is an essay. However, in the textbooks published by Yudhistira found multiple-choice questions, matchmaking, and short essay. Whereas, all the items were not found in the textbook published by Puskurbuk and Erlangga.

Essay written test has the aim to facilitate students to think at a higher level (higher-order thinking skill). Although the analysis found the question by choosing the correct answer, such as multiple-choice, matchmaking, and short essay. But, Permendikbud number 23 of 2016, states that the curriculum 2013 no longer uses the type of assessment of choosing the answers (Eliawati et al., 2017; Peraturan Menteri Pendidikan dan Kebudayaan Republik Indonesia Nomor 23 tahun 2016 tentang standar penilaian pendidikan, 2016).

\section{Comparison of the Contents of Scientific}

Approaches and Authentic Assessments in Textbooks of Curriculum 2013

In the aspect of the scientific approach, the most comprehensive textbook of curriculum 2013 was published by Erlangga because it has the highest number for the fulfilment of the indicators in the scientific approach. (Fadlillah, 2014 , p. 176) states, a scientific approach is a learning approach that carries out through the process of observing, questioning, experimenting, associating, and communicating.

In the authentic assessment aspect, the textbooks of Curriculum 2013 published by Puskurbuk and Yudhistira have completed indicators. (Bosco \& Ferns, 2014, p. 282) states that "An authentic assessment usually involves a single task that holds some relevance to the realworld setting and is formally evaluated within the curricula." (Dennis et al., 2013, p. 194) support that, "authentic assessment provides the foundation for the establishment of meaning-ful instructional practices for young children."

\section{Conclusion}

The scientific approach in the textbook of curriculum 2013 consists of five aspects, namely observing, asking, trying or experimenting, reasoning or associating, and communicating, which are not always sequentially. So, not all indicators on every aspect are found in every sub-theme. Erlangga published the most comprehensive textbook of curriculum 2013 because it has the highest number for the fulfilment of the indicators. The authentic assessment consists of three aspects, namely attitude assessment (social and spiritual), skills assessment which only includes an assessment of practices, products, and projects, and assessment of knowledge without verbal tests and assignments. In the authentic assessment aspect, the textbooks of curriculum 2013 published by Puskurbuk and Yudhistira have completed indicators.

\section{References}

Asep, J., \& Abdul, H. (2008). Evaluasi pembelajaran. Multi Pressindo.

Berk, L. E. (2013). Development through the lifespan. Pearson.

Bosco, A. M., \& Ferns, S. (2014). Embedding of authentic assessment in work-integrated learning curriculum. Asia-Pacific Journal of Cooperative Education, 15(4), 281-290.

Boyd, D. R., Bee, H. L., \& Santrock, J. W. (2012). Life-span development. McGrawHill Education.

Chiappetta, E. L., \& Koballa, T. R. (2010). Science instruction in the middle and secondary schools: Developing fundamental knowledge and skills. Allyn \& Bacon.

Cumming, J. J., \& Maxwell, G. S. (1999). Contextualising authentic assessment. Assessment in Education: Principles, Policy \& Practice, 6(2), 177-194. https://doi.org/10.1080/09695949992865

Dennis, L. R., Rueter, J. A., \& Simpson, C. G. (2013). Authentic assessment: Establishing a clear foundation for instructional practices. Preventing School Failure: Alternative Education for Children and Youth, 57(4), 189-195. https://doi.org/10.1080/1045988X.2012.6 81715

Dewanti, S. R., Ramli, M., \& Rahmawati, N. R. (2018). Pengembangan paket bimbingan rasa hormat untuk siswa sekolah dasar. Jurnal Pendidikan: Teori, Penelitian, Dan Pengembangan, 3(3), 365-370. https://doi.org/10.17977/jptpp.v3i3.10658

Direktorat Pembinaan Sekolah Dasar. (2016). Panduan teknis pembelajaran dan penilaian di sekolah dasar. In Jakarta: Kementrian Pendidikan dan Kebudayaan.

Dyer, J., Gregersen, H., \& Christensen, C. M. (2011). The innovator's DNA: Mastering the five skills of disruptive innovation. Harvard Business Review Press.

Eddy, P. L., \& Lawrence, A. (2013). Wikis as platforms for authentic assessment. 
Jurnal Prima Edukasia, 7 (2), 2019 - 138

Maryati Maryati, Enny Zubaidah, Ali Mustadi

Innovative Higher Education, 38(4), 253265. https://doi.org/10.1007/s10755-0129239-7

Eliawati, E., Pitoewas, B., \& Yanzi, H. (2017). Sikap guru terhadap standar penilaian Kurikulum $2013 \quad$ berdasarkan Permendikbud nomor 23. Jurnal Kultur Demokrasi, 5(4).

Fadlillah, M. (2014). Implementasi Kurikulum 2013 dalam pembelajaran SD/MI, SMP/MTs, \& SMA/MA. Ar-Ruzz Media.

Gerde, H. K., Schachter, R. E., \& Wasik, B. A. (2013). Using the scientific method to guide learning: an integrated approach to early childhood curriculum. Early Childhood Education Journal, 41(5), 315323. https://doi.org/10.1007/s10643-0130579-4

Goldston, M. J., \& Downey, L. (2013). Your science classroom: Becoming an elementary/middle school science teacher. SAGE Publications.

Joughin, G. (2010). A short guide to oral assessment. Leeds Met Press in association with University of Wollongong.

Kovalik, S., \& Olsen, K. (Karen D. . (2010). Kid's eye view of science : a conceptual, integrated approach to teaching science, $K$-6. Corwin.

Krippendorff, K. (2018). Content analysis: An introduction to its methodology. SAGE Publications Ltd.

Mak, D. K., Mak, A. T., \& Mak, A. B. (2009). Solving everyday problems with the scientific method: thinking like a scientist. World Scientific.

Peraturan Menteri Pendidikan dan Kebudayaan Republik Indonesia Nomor 23 tahun 2016 tentang standar penilaian pendidikan, Pub.
L. No. 23 (2016).

Nitko, A. J., \& Brookhart, S. M. (2011). Educational assessment of students. Pearson/Allyn \& Bacon.

Ongowo, R. O., \& Indoshi, F. C. (2013). Science process skills in the Kenya certificate of secondary education biology practical examinations. Creative Education, 04(11), 713-717. https://doi.org/10.4236/ce.2013.411101

Saefuddin, A., \& Berdiati, I. (2014). Pembelajaran efektif. Remaja Rosdakarya.

Schunk, D. H. (2012). Learning theories: An educational perspective. Pearson.

Settlage, J., \& Southerland, S. (2012). Teaching science to every child: Using culture as a starting point. Routledge.

Shamsudin, N. M., Abdullah, N., \& Yaamat, N. (2013). Strategies of teaching science using an inquiry based science education (IBSE) by Novice Chemistry Teachers. Procedia - Social and Behavioral Sciences, $\quad 90, \quad 583-592$. https://doi.org/10.1016/j.sbspro.2013.07.1 29

Spiller, D. (2012). Assessment matters: Selfassessment and peer assessment. The University of Waikato.

Van Blerkom, M. L. (2009). Measurement and statistics for teachers. Routledge.

Wijaya, W. (2013). Pembelajaran Kurikulum 2013. Remaja Rosdakarya.

Zaim, M. (2017). Implementing scientific approach to teach English at senior high school in Indonesia. Asian Social Science, 13(2), 33-40. https://doi.org/10.5539/ass.v13n2p33 